\title{
Methods of Isolation and Characterization of Stem Cells from Different Regions of Oral Cavity Using Markers: A Systematic Review
}

\author{
Kavarthapu Avinash, Sankari Malaippan, Jayakumar Nadathur Dooraiswamy \\ Department of Periodontology, Saveetha Dental College, Chennai, India
}

\begin{abstract}
Background: Periodontitis is a destructive inflammatory disorder of the periodontium caused by the destruction of periodontal tissues namely the PDL, cementum, alveolar bone, and gingiva. Once these tissues are lost, the foremost goal of periodontal therapy is to regenerate the diseased tissues if possible to their original form, architecture, and function. Various regenerative procedures were employed and still a gap was found in achieving the goal. As stem cells are characterized by their ability to self-renew and differentiate to produce specialized cells, there could be a possibility of using them for regenerative therapy. Recently, dental tissues such as the PDL, the dental pulp and the tooth follicle have been recognized as readily available sources of adult stem cells.

Aim: The aim was to identify the various sources and methodologies in isolation of stem cells from human oral cavity and its differentiation into various lineages using markers.

Materials and Methods: The electronic databases PUBMED, GOOGLE SCHOLAR, SCIENCE DIRECT, COCHRANE LIBRARY along with a complimentary manual search of all periodontics journal till the year 2016. Thirteen articles were selected on the basis of the inclusion criteria. Isolation of stem cells from oral cavity through various methods has been evaluated and similarly characterization to different lineages were tabulated as variables of interest. They included human in-vitro and ex-vivo studies.

Results: The results showed that PDLSC's and pulpal stem cells are the most common source from where stem cells were isolated. Each source has used different methodology in isolating the stem cells and it was found that STRO-1 was the commonly used marker in all the studies mentioned.

Conclusions: The studies showed that there is no standard protocol existed in isolating the stem cells from different sources of oral cavity. Moreover, there was no standard marker or methodology used in characterization.
\end{abstract}

Keywords: Oral stem cell, Dental stem cell, Periodontal ligament stem cell, Gingival stem cell, Pulpal stem cell

\footnotetext{
Accepted for publication April 10, 2017, Published online May 30, 2017 Correspondence to Kavarthapu Avinash

Department of Periodontology, Saveetha Dental College, Ponamalle High Road, Chennai 600077, Tamilnadu, India

Tel: +919840379213, Fax: +918592234577

E-mail: avin_sourav@hotmail.com

(c) This is an open-access article distributed under the terms of the Creative Commons Attribution Non-Commercial License (http://creativecommons.org/ licenses/by-nc/4.0/), which permits unrestricted non-commercial use, distribution, and reproduction in any medium, provided the original work is properly cited.

Copyright (c) 2017 by the Korean Society for Stem Cells Research
}

\section{Background}

Stem cell research is the most fascinating area of interest today. The discovery of stem cells dates back in 1950`s when various experiments with bone marrow established their identity and their powerful role in regeneration of lost tissues. Earlier studies on human development had demonstrated that cells of embryo were able to produce every cell type in the body. Ernst Heinrich Philipp August Haeckel was the first person who described a fertilized ovule which would evolve into an organism (1). The team of scientists from the university of Madison were the first 
to isolate human embryonic stem cells in the laboratory. These isolated stem cells that retained their ability to transform into a variety of cell types including bone, cartilage, nerve and muscle cells (2).

Stem cells are uncommitted entities capable of both self-renewal and differentiation into multiple lineages (3, 4). They are unspecialized cells that renew themselves for long periods through cell division and under certain physiologic conditions they may be induced to become cells with special function. These two features distinguish stem cells from other cells types. Furthermore, stem cells have been recognized with varying degree of potency into three different categories: embryonic stem cells, induced pluripotent stem cells and adult stem cells. The ability of pluripotency and differentiation in the cells derived from the embryonic germ layers in-vitro, in-vivo and ex-vivo lead the embryonic stem cells as the main source of tissue regeneration and in regenerative medicine in the treatment of parkinsonism, cardiac diseases and diabetes (5). In spite of its advantageous use of embryonic stem cells in the field of medicine, it has become problematic because of ethical issues involving the use of human blastocytes as a biological research material.

To overcome this, it has been started to isolate stem cells from oral cavity. They are classified as Mesenchymal stem cells (MSCs), Adult stem cells (ASCs), Tissue stem cells (TSCs) (6). MSCs are considered as ideal source of adult stem cells. The characteristic features of them are their extraordinary plasticity that retain their multi-lineage potential when spread into groups as colonies. However, the first mesenchymal stem cell that is isolated from oral cavity was the dental pulp stem cells (DPSCs) (7). After isolating stem cells from DPSCs, stem cells were being isolated from the various regions of the oral cavity by using different methods and has been differentiated to various lineages. Hence, this systematic review aims to identify the various sources and methodologies of isolation of stem cells from human oral cavity and its differentiation into various lineages using markers.

\section{Materials and Methods}

The electronic databases PUBMED, GOOGLE SCHOLAR, SCIENCE DIRECT, COCHRANE LIBRARY along with a complimentary manual search of all periodontics journal till the year 2016. No limits and language restriction were applied during the electronic search in order to include all the relevant articles pertaining to the topic of interest. The search in PUBMED yielded 149 articles which were screened based on the relevance of the title and abstract to the topic of interest. 125 articles were excluded based on this criterion. The full texts of the 24 articles were analysed, of which 12 were excluded based on the exclusion criteria of this systematic review. Only one relevant article could be extracted through hand search and no articles were retrieved from other data bases. The inclusion criteria include in-vitro and ex-vivo studies where the tissue was obtained purely from oral cavity of human samples, those in which both the isolation and differentiation of stem cells were analysed and all there was no restriction in the usage of the markers. Studies where the source was from animals, and where only isolation of stem cells were done were excluded from the study.

\section{Results}

The literature searches from the electronic databases revealed 149 articles, of which 125 articles were excluded based on the irrelevance of the abstract and title to this review. Furthermore, 12 articles were excluded after analyzing the full text based on the exclusion criteria. So, a total of 12 articles were included based on electronic search. On hand search, only one relevant article was obtained. Hence, a total of 13 studies were included for the data to be extracted and the characteristics of the included studies along with the summary of its results. Then the articles were segregated and the data was tabulated according to the different aspects of the structured question on methods of isolation of stem cells from oral cavity and its characterization.

The following results can be summarized according to the three parts of the research question on methods of stem cell isolation and its characterization from oral cavity:

\section{What are the different sources of stem cells from oral cavity?}

There are various sources of tissue available in the human oral cavity from where stem cells can be isolated. Fig. 1 depicts the different regions of the oral cavity from where the stem cells can be isolated. All the 13 articles obtained were relevant to this aspect. The different sources of tissue in the oral cavity from where stem cells can be isolated include periodontal ligament, apical papilla, alveolar bone, dental pulp tissue, maxillary sinus, periodontal ligament granulation tissue and gingiva.

Considering the source of the tissue, the distribution of studies was as follows: four from the periodontal ligament (8-11), four from the dental pulp (12-15), two from apical papilla $(15,16)$, two from alveolar bone $(17,18)$, one from 


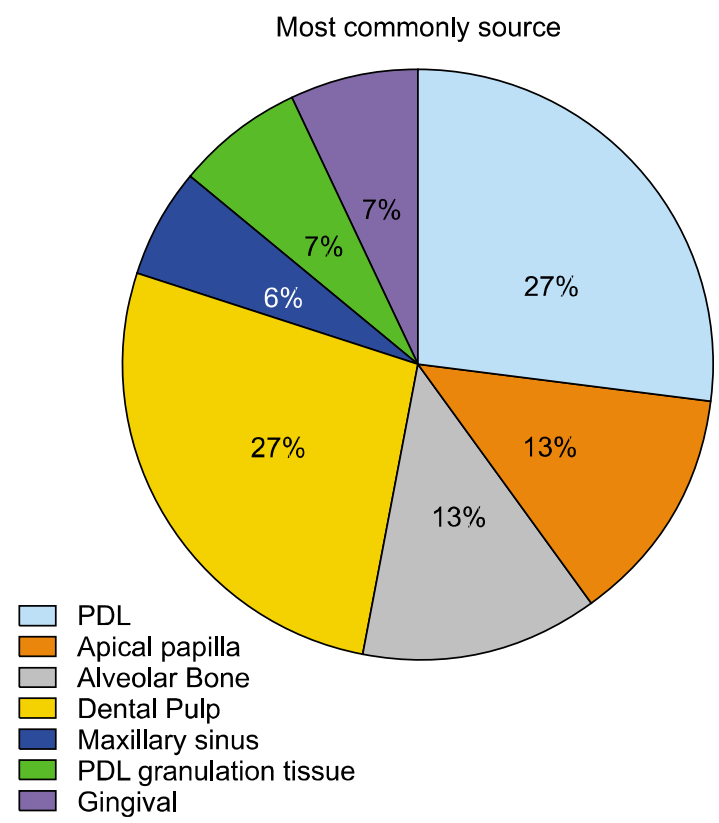

Fig. 1. Describe the source of tissue from various regions of oral cavity.

maxillary sinus (19), periodontal ligament granulation tissue (20) and gingiva (18) each. Considering the most common and feasible source of stem cells, from the articles obtained, it can be said that most commonly, sources like periodontal ligament and dental pulp tissue was used for isolation of stem cells and was depicted in Fig. 1. The reason could be due to the fact that, these two sources like periodontal ligament and dental pulp were obtained from the tooth/ teeth that has been extracted for the purpose of orthodontic reasons or as a procedure of impaction.

\section{What are the different methodologies used in the isolation of stem cells from oral cavity?}

Articles describing about the methodology of isolation of stem cells from oral cavity were included. Surprisingly, it was found that there is a lot of difference observed in the methodology of isolation of stem cells. Mentioning the methodology, eleven out of thirteen articles shows that the isolation stem cells was purely from cultures but in two studies where the source of tissue was from periodontal ligament (8) and dental pulp (13) used methods like cell culture and magnetic activated cell sorting.

Dispase is a protease which cleaves fibronectin, collagen IV, and to a lesser extent collagen I. In majority of the studies $4 \mathrm{mg} / \mathrm{ml}$ dispase I was being used, but it was found that there is a variation in the proportion of dispase being used. In 4 studies, $2 \mathrm{mg} / \mathrm{ml}$ dispase I and in one study, $4 \mathrm{mg} / \mathrm{ml}$ dispase II was used for digestion. In a
Table 1. Summary of the results of the included studies based on most commonly used methods of identification after differentiation

\begin{tabular}{clc}
\hline S.No & \multicolumn{1}{c}{ Method Used } & No of Studies \\
\hline 1 & Phase contrast inverted microscope & 8 \\
2 & RT-PCR & 7 \\
3 & Flow Cytometry & 6 \\
4 & Colony Forming Units & 5 \\
5 & Immunofluoroscence & 3 \\
6 & Protein Extraction and Immunoblotting & 2 \\
\hline
\end{tabular}

study where the isolation was from maxillary sinus used collagenase alone but does not used dispase to digest the tissue.

Similarly, there was a variation observed in the proportion of collagenase being used to digest the collagen. In 9 studies, $3 \mathrm{mg} / \mathrm{ml}$ collagenase I and in 3 studies 0.2 $\mathrm{mg} / \mathrm{ml}$ collagenase I was used respectively. But, in a study where the isolation was from maxillary sinus used $0.06 \%$ type II collagen.

Digestion or incubation time plays an important role in culturing the cells. There was no specific protocol being followed for the incubation time. In all the studies obtained, a minimum incubation time of $40 \mathrm{~min}$ was maintained for digestion. More commonly, one-hour incubation time is given before culturing. In two studies, the incubation time was prolonged to $70 \mathrm{~min}$ and the maximum incubation time given for digestion was for 2 hours. Though there is a variation in the incubation time, the temperature in all the studies is maintained at $37^{\circ} \mathrm{C}$.

In addition to digestion of tissue by enzymes, straining of the cells also plays an important role in culturing the cells. Majority of the studies have used $70 \mu \mathrm{m}$ strainer which only allows cells of its size and less and leave out all the debris material. A filter pore size of $40 \mu \mathrm{m}$ was used in a study where the source of tissue was from maxillary sinus. Two studies did not strain the cells as they let all the cells to be grown over the medium.

\section{What are the different markers used in differentiation of oral stem cells and which is most commonly used?}

After isolation of stem cells, differentiating occurs through various markers and by various methods. The cells obtained during this differentiation includes osteoblasts, odontoblasts, cementoblasts, chondroblasts, chondrocytes, adipocytes, neuroblast, angioblast and fibroblasts. Majority of the studies used phase contrast inverted microscope, flow cytometry and RT-PCR in identification of differentiated cells which was tabulated (Table 1). The most common method used in identification of cells was 


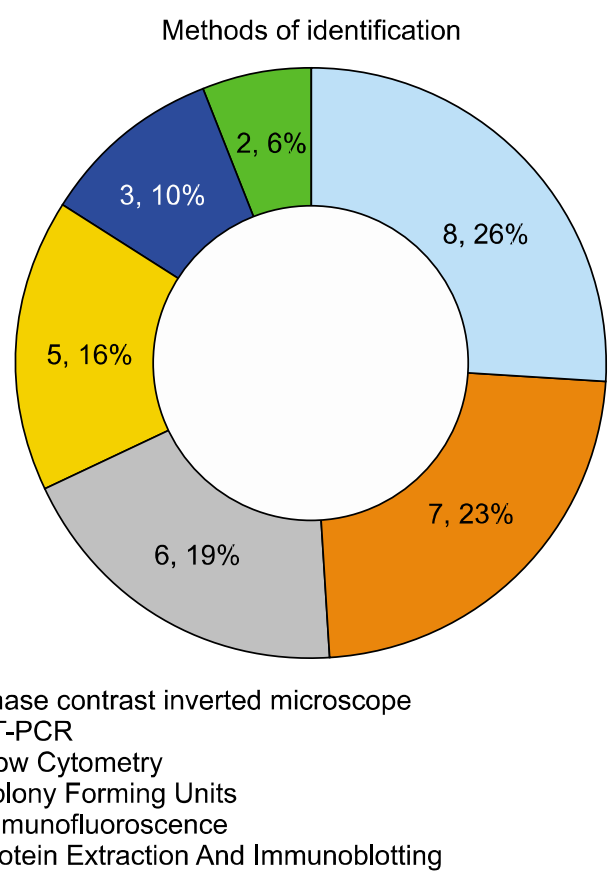

Fig. 2. Describe the methods of identification of various cells.

described in Fig. 2. Among thirteen studies, ten studies described about characterization to osteoblasts. The source of this cells is from dental pulp, periodontal ligament, alveolar bone, apical papilla and maxillary sinus. STRO-1, the common marker that was commonly used in all the studies in differentiating to osteoblasts. Not only in differentiating to osteoblasts, but it was used as a common marker for many differentiating to many cells and was depicted in Fig. 3. In addition to this, OCT-4, NANOG and SOX-2 were also used for differentiation. The next common cell that was characterized was adipocytes which was obtained from dental pulp, PDL granulation tissue, alveolar bone and apical papilla. The markers that were used to identify adipocytes were STRO-1, ALP, CD29, CD34, CD44. Odontoblasts were the cells that were being differentiated from the various tissues next to osteoblasts and adipocytes and it was described only in two studies included. The markers for this are similar to that of the osteoblasts. Two studies described about differentiating to neuroblasts and one study about angioblasts. For both the cells the common source was from dental pulp. They share a common marker in identification like Nestin and Nucleostemin in addition to SOX-2. Fibroblasts were obtained from maxillary sinus tissue using the marker STRO-1. Chondroblasts and chondrocytes were obtained from dental pulp in common but former was also isolated from gingival tissue and alveolar bone but later from PDL and PDL granulation tissue. The common marker used

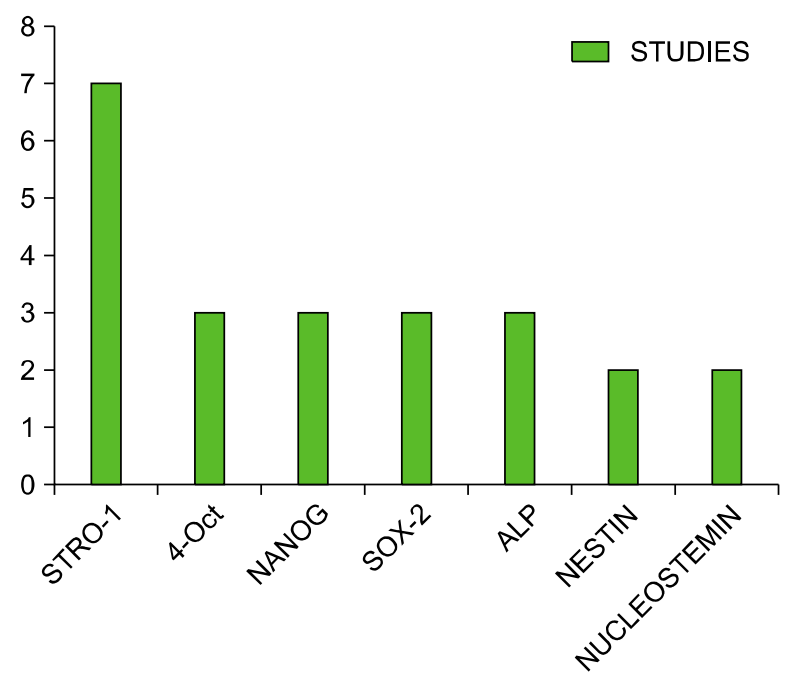

Fig. 3. Describe the various markers used for differentiation to various cells.

for both was STRO-1. The description of the results was detailed in Table 2.

\section{Discussion}

Periodontitis is a destructive inflammatory disorder of the periodontium branded by the destruction of periodontal tissues namely the PDL, cementum, alveolar bone, and gingiva. Once these tissues are lost, the foremost goal of periodontal therapy is to regenerate the diseased tissues if possible to their original form, architecture, and function. This a demanding task, that requires the harmonization of many actions at both cellular and molecular levels. Successful periodontal regeneration encompasses the formation of new gingival connective tissue, the restoration of bone, and most decisively, the insertion of new connective tissue fibers into newly formed cementum on the formerly diseased root surfaces. A variety of procedures to regenerate the lost tissue have been suggested, including the utilization of the principles of guided tissue regeneration and the application of an assortment of growth factors as well as bone and enamel matrix proteins on the root surfaces. However, these strategies showed only limited regeneration of periodontal tissue and were associated with incoherent and unpredictable clinical outcomes. Stem cells are progenitor cells characterized by their ability to self-renew and differentiate to produce specialized cells. There are two main categories of stem cells, the pluripotent embryonic stem cells and the multipotent adult ones. In this systematic review, it describes about the various methods of isolation of stem cells from oral cavity and 
Table 2. Summary of the extracted studies in detail

\begin{tabular}{|c|c|c|c|c|c|c|c|c|}
\hline S.no & Author & Source of isolation & Methodology & $\begin{array}{l}\text { Culture } \\
\text { time }\end{array}$ & $\begin{array}{c}\% \text { of } \\
\mathrm{CO}_{2} \text { used }\end{array}$ & Identified through & $\begin{array}{c}\text { Markers } \\
\text { used }\end{array}$ & $\begin{array}{c}\text { Characterized } \\
\text { to }\end{array}$ \\
\hline 1 & $\begin{array}{l}\text { Seo } \\
\text { et al., } \\
2004\end{array}$ & $\begin{array}{l}\text { PDL tissue was } \\
\text { obtained from } \\
\text { surgically } \\
\text { extracted human } \\
\text { third molars }\end{array}$ & $\begin{array}{l}\mathrm{PDL} \text { digested in } 3 \mathrm{mg} / \mathrm{ml} \\
\text { collagenase type and } 4 \\
\mathrm{mg} / \mathrm{ml} \text { dispase for } 1 \mathrm{~h} \text { at } \\
37^{\circ} \mathrm{C} \\
\text { Cell suspensions filtered with } \\
70 \mu \mathrm{m} \text { cell strainer }\end{array}$ & $\begin{array}{l}10 \\
\text { days }\end{array}$ & $\begin{array}{r}5 \% \mathrm{CO}_{2} \\
\text { at } 37^{\circ} \mathrm{C}\end{array}$ & $\begin{array}{l}\text { 1. Immunohistochemistry } \\
\text { 2. RT-PCR } \\
\text { 3. Western blot analysis } \\
\text { 4. Northern blot analysis }\end{array}$ & $\begin{array}{r}\text { STRO-1, } \\
\text { CD146 }\end{array}$ & Cementoblast \\
\hline 2 & $\begin{array}{l}\text { Kim } \\
\text { et al., } \\
2005\end{array}$ & $\begin{array}{l}\text { Periodontal } \\
\text { ligament middle } \\
3^{\text {rd }} \text { of maxillary } \\
\text { premolar extracted } \\
\text { due to orthodontic } \\
\text { reasons }\end{array}$ & $\begin{array}{l}\text { Tissue digested with } 3 \mathrm{mg} / \mathrm{ml} \\
\text { collagenase I+ } 4 \mathrm{mg} / \mathrm{ml} \\
\text { dispase I for } 1 \mathrm{~h} \text { at } 37^{\circ} \mathrm{C} \\
\text { Cell suspensions filtered with } \\
70 \mu \mathrm{m} \text { cell strainer }\end{array}$ & $\begin{array}{l}2 \sim 3 \\
\text { days }\end{array}$ & $\begin{array}{r}5 \% \mathrm{CO}_{2} \\
\text { at } 37^{\circ} \mathrm{C}\end{array}$ & $\begin{array}{l}\text { 1. Colony formation } \\
\text { assays } \\
\text { 2. Fluorescent activated } \\
\text { cell sorting } \\
\text { 3. Cell proliferation assay }\end{array}$ & $\begin{array}{l}\text { CD29, } \\
\text { CD34, } \\
\text { CD44 } \\
\text { STRO-1 }\end{array}$ & $\begin{array}{l}\text { Osteoblasts } \\
\text { Chondroblasts } \\
\text { Adipocytes }\end{array}$ \\
\hline 3 & $\begin{array}{r}\text { Laino, } \\
2006\end{array}$ & $\begin{array}{l}\text { Human dental } \\
\text { pulp has been } \\
\text { extracted from } \\
\text { exfoliated } \\
\text { deciduous teeth. }\end{array}$ & $\begin{array}{l}\text { Pulp was removed and } \\
\text { immersed in a digestive } \\
\text { solution: } 100 \mathrm{U} / \mathrm{ml} \text { penicillin, } \\
100 \mathrm{mg} / \mathrm{ml} \text { streptomycin, } \\
500 \mathrm{mg} / \mathrm{ml} \text { claritromycin in } 4 \\
\mathrm{ml} \mathrm{PBS} \text {, added of } 3 \mathrm{mg} / \mathrm{ml} \\
\text { type I collagenase, } 4 \mathrm{mg} / \mathrm{ml} \\
\text { dispase for } 1 \mathrm{~h} \text { at } 37^{\circ} \mathrm{C} \\
\text { Cell suspensions filtered with } \\
70 \mu \mathrm{m} \text { cell strainer }\end{array}$ & $\begin{array}{c}3 \sim 4 \\
\text { days }\end{array}$ & $\begin{array}{r}5 \% \mathrm{CO}_{2} \\
\text { at } 37^{\circ} \mathrm{C}\end{array}$ & $\begin{array}{l}\text { 1. Colony efficiency } \\
\text { assays and } \\
\text { proliferation potential } \\
\text { 2. Monoclonal antibodies } \\
\text { and flow cytometry } \\
\text { 3. Histochemistry \& } \\
\text { Immunofluorescence } \\
\text { 4. RT-PCR }\end{array}$ & $\begin{array}{l}\text { STRO-1, } \\
\text { CD34 } \\
\text { RUNX-2 }\end{array}$ & Osteoblasts \\
\hline 4 & $\begin{array}{l}\text { Gay } \\
\text { et al., } \\
2007\end{array}$ & $\begin{array}{l}\text { Periodontal tissues } \\
\text { from impacted } \\
\text { third molars }\end{array}$ & $\begin{array}{l}\text { Tissue digested with } 3 \mathrm{mg} / \mathrm{ml} \\
\text { collagenase } \mathrm{I}+4 \mathrm{mg} / \mathrm{ml} \\
\text { dispase I for } 1 \mathrm{~h} \text { at } 37^{\circ} \mathrm{C} \\
\text { Cell suspensions filtered with } \\
70 \mu \mathrm{m} \text { cell strainer }\end{array}$ & $\begin{array}{l}\text { Not } \\
\text { men- } \\
\text { tioned }\end{array}$ & $\begin{array}{r}5 \% \mathrm{CO}_{2} \\
\text { at } 37^{\circ} \mathrm{C}\end{array}$ & $\begin{array}{l}\text { 1. FACS sorting and cell } \\
\text { culture } \\
\text { 2. Cell growth rate assay } \\
\text { 3. Clonogenic assays } \\
\text { 4. Immunohistochemisty } \\
\text { 5. RT-PCR analysis }\end{array}$ & $\begin{array}{l}\text { STRO-1 } \\
\text { ALP }\end{array}$ & $\begin{array}{l}\text { Osteoblasts } \\
\text { Chondrocytes } \\
\text { Adipocytes }\end{array}$ \\
\hline 5 & $\begin{array}{l}\text { Jo } \\
\text { et al., } \\
2007\end{array}$ & $\begin{array}{l}\text { Dental pulpal tissue } \\
\text { and tooth germ } \\
\text { from apical papilla } \\
\text { Alveolar bone } \\
\text { fragments of } \\
\text { impacted } 3^{\text {rd }} \text { molar }\end{array}$ & $\begin{array}{l}\text { Bone segments digested with } \\
3 \mathrm{mg} / \mathrm{ml} \text { collagenase } \mathrm{I}+ \\
4 \mathrm{mg} / \mathrm{ml} \text { dispase I for } 1 \mathrm{~h} \\
\text { at } 37^{\circ} \mathrm{C} \\
\text { Cell suspensions filtered with } \\
70 \mu \mathrm{m} \\
\text { Cell strainer }\end{array}$ & & $\begin{array}{r}5 \% \mathrm{CO}_{2} \\
\text { at } 37^{\circ} \mathrm{C}\end{array}$ & $\begin{array}{l}\text { 1. Immunohistochemistry- } \\
\text { 2. Alp activity } \\
\text { 3. RT-PCR }\end{array}$ & $\begin{array}{c}\text { STRO-1, } \\
\text { CD29 }\end{array}$ & $\begin{array}{l}\text { Osteocytes, } \\
\text { adipocytes }\end{array}$ \\
\hline 6 & $\begin{array}{l}\text { Kim } \\
\text { et al., } \\
2009\end{array}$ & $\begin{array}{l}\text { Maxillary sinus } \\
\text { tissue was } \\
\text { obtained during } \\
\text { orthognathic } \\
\text { surgery }\end{array}$ & $\begin{array}{l}\text { Maxillary sinus tissue } \\
\text { was digested in PBS with } 1 \% \\
\text { antibiotic and antimycotic } \\
\text { solution } \\
\text { It is then cut into small pieces } \\
\& \text { treated with } 0.06 \% \\
\text { collagenase type } 1 \mathrm{II} \text {. Alpha } \\
\text { MEM containing } 10 \% \text { fetal } \\
\text { bovine serum and } 1 \% \\
\text { penicillin-streptomycin. Cell } \\
\text { strained with } 40 \mu \mathrm{m} \text { cell } \\
\text { strainer }\end{array}$ & days & $\begin{array}{r}5 \% \mathrm{CO}_{2} \\
\text { at } 37^{\circ} \mathrm{C}\end{array}$ & $\begin{array}{l}\text { 1. Colony-Forming Unit } \\
\text { Fibroblast Assay } \\
\text { 2. Flow Cytometry } \\
\text { 3. Alkaline Phosphatase } \\
\text { Staining } \\
\text { 4. RT-PCR }\end{array}$ & $\begin{array}{r}\text { STRO-1, } \\
\text { CD105 }\end{array}$ & $\begin{array}{l}\text { Fibroblasts, } \\
\text { osteoblasts }\end{array}$ \\
\hline 7 & $\begin{array}{l}\text { Yu } \\
\text { et al., } \\
2010\end{array}$ & $\begin{array}{l}\text { DPSCs were } \\
\text { enzymically } \\
\text { isolated from } \\
\text { dental pulps of } \\
\text { human molars }\end{array}$ & $\begin{array}{l}\text { Magnetic activated cell sorting } \\
\text { (MACS), dental } \\
\text { pulp digested with } 3 \mathrm{mg} / \mathrm{ml} \\
\text { collagenase } \mathrm{I}+4 \mathrm{mg} / \mathrm{ml} \\
\text { dispase I for } 1 \mathrm{~h} \text { at } 37^{\circ} \mathrm{C} \\
\text { Cell suspensions filtered with } \\
70 \mu \mathrm{m} \text { cell strainer }\end{array}$ & & $\begin{array}{r}5 \% \mathrm{CO}_{2} \\
\text { at } 37^{\circ} \mathrm{C}\end{array}$ & $\begin{array}{l}\text { 1. RT-PCR } \\
\text { 2. Western blot test } \\
\text { 3. ALP assay and } \\
\text { alizarin red staining- }\end{array}$ & $\begin{array}{l}\text { Stro-1 } \\
\text { ALP } \\
\text { RUNX2 }\end{array}$ & $\begin{array}{c}\text { Odontoblasts, } \\
\text { osteoblasts, } \\
\text { chondrocytes }\end{array}$ \\
\hline
\end{tabular}


Table 2. Continued

\begin{tabular}{|c|c|c|c|c|c|c|c|c|}
\hline S.no & Author & Source of isolation & Methodology & $\begin{array}{l}\text { Culture } \\
\text { time }\end{array}$ & $\begin{array}{c}\% \text { of } \\
\mathrm{CO}_{2} \text { used }\end{array}$ & Identified through & $\begin{array}{c}\text { Markers } \\
\text { used }\end{array}$ & $\begin{array}{c}\text { Characterized } \\
\text { to }\end{array}$ \\
\hline 8 & $\begin{array}{l}\text { Karba- } \\
\text { nova } \\
\text { et al., } \\
2011\end{array}$ & $\begin{array}{l}\text { Dental pulp of } \\
\text { Healthy Impacted } \\
\text { third molars } \\
\text { extracted for } \\
\text { orthodontic } \\
\text { reasons }\end{array}$ & $\begin{array}{l}\text { Tissue digested with } \\
\text { collagenase- } 0.2 \mathrm{mg} / \mathrm{ml} \mathrm{\&} \\
2 \mathrm{mg} / \mathrm{ml} \text { dispase for } 70 \mathrm{~min} \\
\text { at } 37^{\circ} \mathrm{C} \\
\text { Cell strained with } 70 \mu \mathrm{m} \text { cell } \\
\text { strainer }\end{array}$ & $\begin{array}{r}5 \sim 10 \\
\text { days }\end{array}$ & $\begin{array}{r}5 \% \mathrm{CO}_{2} \\
\text { at } 37^{\circ} \mathrm{C}\end{array}$ & $\begin{array}{l}\text { 1. Cell culture } \\
\text { 2. Cell surface } \\
\text { immunofluorescence } \\
\text { 3. Flow cytometry } \\
\text { 4. Protein extraction } \\
\text { and Immunoblotting } \\
\text { 5. RT-PCR analysis }\end{array}$ & $\begin{array}{l}\text { STRO-1, } \\
\text { OCT-4 } \\
\text { Nanog, } \\
\text { Sox-2 } \\
\text { Nestin } \\
\text { Nucleost } \\
\text { emin }\end{array}$ & $\begin{array}{l}\text { Osteoblasts } \\
\text { Chondroblast } \\
\text { Neuroblast } \\
\text { angioblast }\end{array}$ \\
\hline 9 & $\begin{array}{l}\text { Naohisa } \\
\text { et al., } \\
2011\end{array}$ & $\begin{array}{l}\text { Periodontal } \\
\text { ligament from } \\
\text { middle } 3^{\text {rd }} \text { of root } \\
\& \text { gingival tissue } \\
\text { during crown } \\
\text { lengthening } \\
\text { procedures in } \\
\text { premolar region }\end{array}$ & $\begin{array}{l}\text { Cell culture: Tissue digested } \\
\text { with } 3 \mathrm{mg} / \mathrm{ml} \text { collagenase I } \\
\text { and } 4 \mathrm{mg} / \mathrm{ml} \text { Dispase II for } \\
2 \text { hours at } 37^{\circ} \mathrm{C} \text { for } 2 \mathrm{~h} \text {. } \\
70 \mu \mathrm{m} \text { cell strainer }\end{array}$ & & $\begin{array}{rr}5 \% & \mathrm{CO}_{2} \\
\text { at } & 37^{\circ} \mathrm{C}\end{array}$ & $\begin{array}{l}\text { 1. RT-PCR } \\
\text { 2. Immunofluorescent } \\
\text { staining }\end{array}$ & $\begin{array}{l}\text { OCT3/4, } \\
\text { SOX2, } \\
\text { KLF4 }\end{array}$ & $\begin{array}{l}\text { Neuroblsats, } \\
\text { Chondroblasts }\end{array}$ \\
\hline 10 & $\begin{array}{l}\text { Wu } \\
\text { et al., } \\
2012\end{array}$ & $\begin{array}{l}\text { Apical papilla of } \\
\text { human third } \\
\text { molars with } \\
\text { immature } \\
\text { developing roots }\end{array}$ & $\begin{array}{l}\text { Apical papilla digested with } \\
3 \mathrm{mg} / \mathrm{ml} \text { collagenase } \mathrm{I}+4 \\
\mathrm{mg} / \mathrm{ml} \text { dispase I for } 40 \mathrm{~min} \\
\text { at } 37^{\circ} \mathrm{C} \\
\text { Cell suspensions filtered with } \\
70 \mu \mathrm{m} \text { cell strainer }\end{array}$ & $\begin{array}{c}2 \sim 3 \\
\text { days }\end{array}$ & $\begin{aligned} & 5 \% \mathrm{CO}_{2} \\
& \text { at } 37^{\circ} \mathrm{C}\end{aligned}$ & $\begin{array}{l}\text { 1. Colony-Forming } \\
\text { Assays } \\
\text { 2. ALP Activity Assay- } \\
\text { 3. In Vitro } \\
\text { mineralization Assay } \\
\text { 4. QT-PCR }\end{array}$ & $\begin{array}{l}\text { STRO-1, } \\
\text { Oct4, } \\
\text { Nanog, } \\
\text { Sox2, } \\
\text { and } \\
\text { Rex1 }\end{array}$ & $\begin{array}{l}\text { Osteoblasts } \\
\text { odontoblasts }\end{array}$ \\
\hline 11 & $\begin{array}{l}\text { Fawzy } \\
\text { El-Sayed } \\
\text { et al., } \\
2012\end{array}$ & $\begin{array}{l}\text { Extracting } \\
\text { impacted } 3^{\text {rd }} \\
\text { molar teeth with } \\
\text { bone fragments } \\
\text { attached to it }\end{array}$ & $\begin{array}{l}\text { Alveolar bone proper } \\
\text { fragments were minced into } \\
\text { pieces and washed with } \\
\text { alpha-MEM }+100 \mathrm{U} / \mathrm{ml} \\
\text { penicillin }+100 \mu \mathrm{g} / \mathrm{ml} \\
\text { streptomycin }+1 \% \\
\text { amphotericin } \\
\text { Cells were not strained }\end{array}$ & 7 days & $\begin{array}{r}5 \% \mathrm{CO}_{2} \\
\text { at } 37^{\circ} \mathrm{C}\end{array}$ & $\begin{array}{l}\text { 1. Phase contrast } \\
\text { inverted microscope } \\
\text { 2. Gene expression } \\
\text { profile } \\
\text { 3. Flow cytometric } \\
\text { analysis } \\
\text { 4. Colony forming } \\
\text { units (CFU) assay }\end{array}$ & $\begin{array}{l}\text { CD73, } \\
\text { CD90, } \\
\text { CD105, } \\
\text { CD146, } \\
\text { STRO-1 }\end{array}$ & $\begin{array}{l}\text { Osteoblasts } \\
\text { Chondroblasts } \\
\text { Adipocytes }\end{array}$ \\
\hline 12 & $\begin{array}{l}\text { Hung } \\
\text { et al., } \\
2012\end{array}$ & $\begin{array}{l}\text { Periodontal } \\
\text { granulation tissue }\end{array}$ & $\begin{array}{l}\text { 1. Tissue fixed in } 4 \% \\
\text { paraformaldehyde and } \\
\text { embedded in paraffin } \\
\text { 2. } 3 \mathrm{mg} / \mathrm{ml} \mathrm{PBS} \mathrm{with} \\
\text { collagenase I \& } 4 \mathrm{mg} / \mathrm{ml} \\
\text { dispase } \\
\text { Cell suspensions filtered with } \\
70 \mu \mathrm{m} \\
\text { Cell strainer }\end{array}$ & & $\begin{array}{rr}5 \% & \mathrm{CO}_{2} \\
\text { at } & 37^{\circ} \mathrm{C}\end{array}$ & $\begin{array}{l}\text { 1. Immunohistochemistry } \\
\text { 2. Flow cytometry } \\
\text { 3. Colony formation } \\
\text { unit fibroblast } \\
\text { (CFU-f) and } \\
\text { bromodeoxyuridine } \\
\text { incorporation assay }\end{array}$ & $\begin{array}{l}\text { STRO-1, } \\
\text { CD146, } \\
\text { CD90, } \\
\text { CD44 }\end{array}$ & $\begin{array}{l}\text { Osteocytes } \\
\text { Chondrocytes } \\
\text { adipocytes }\end{array}$ \\
\hline 13 & $\begin{array}{l}\text { Kato } \\
\text { et al., } \\
2013\end{array}$ & $\begin{array}{l}\text { Periodontal } \\
\text { ligament of } \\
\text { healthy human } \\
\text { third molars }\end{array}$ & $\begin{array}{l}\text { Magnetic cell sorting } \\
\text { Cell suspensions filtered with } \\
70 \mu \mathrm{m} \text { cell strainer } \\
\text { Cells centrifuged for } 5 \mathrm{~min}\end{array}$ & $\begin{array}{l}5 \text { to } \\
10 \\
\text { days }\end{array}$ & $\begin{aligned} & 5 \% \mathrm{CO}_{2} \\
& \text { at } 37^{\circ} \mathrm{C}\end{aligned}$ & $\begin{array}{l}\text { 1. Cell proliferation } \\
\text { assay } \\
\text { 2. Molecular devices } \\
\text { 3. QT-PCR }\end{array}$ & STRO-1 & Osteoblasts \\
\hline
\end{tabular}

its differentiation to various cells.

Stem cells are uncommitted entities capable of both self-renewal and differentiation into multiple lineages (3, 4). It was reported that many cells that are present in the mature periodontium are like cementoblasts, osteoblasts, fibroblasts, endothelial cells, nerve cells and epithelial cells have the property of a stem or progenitor cell (21). Recently, dental tissues such as the periodontal ligament, the dental pulp, the dental papilla and the tooth follicle have been documented as sources of adult stem/progenitor cells $(14,22-24)$.

PDL was most commonly used tissue that help in isolation to various cells. PDLSCs obtained from mature periodontal ligaments possess stem cell properties similar to MSCs rather than neural crest cells (25). PDLSCs express MSC surface markers and moreover PDLSCs located in 
Table 3. Abbrevation expansions of the data

\begin{tabular}{ccl}
\hline S.No & Abbrevations & \multicolumn{1}{c}{ Expansions } \\
\hline 1 & PDL & Periodontal ligament \\
2 & DPSCs & Dental pulp stem cells \\
3 & $\alpha-$ MEM & $\alpha$-minimum essential medium \\
4 & Sox-2 & SRY (sex determining region Y) box 2 \\
5 & Oct-4 & Octamer-binding transcription factor 4 \\
6 & Nanog & Nanog Homeobox \\
7 & STRO-1 & Stromal Cell Surface Marker-1 \\
8 & ALP & Alkaline phosphotase \\
13 & QT-PCR & Quantitative PCR \\
14 & RT-PCR & Real-time PCR \\
15 & FACS & Fluorescence activated cell sorting \\
\hline
\end{tabular}

the perivascular wall of periodontal ligaments share similarities with pericytes in morphology, differentiation potential, cell phenotype and the ability to form capillary-like structures in vitro. Recently, information about PDLSCs has expanded, but no standard protocol for PDLSC culture and identification is available and this leads to studies that cannot be compared. A consensus about isolating, culturing, identifying, and using PDLSCs is needed. In this review, four studies isolated cells from PDL. There was no difference in the amount and type of collagenase used, but there was no standardization observed in using dispase. Among of dispase being used was same for all the studies but various was observed in the type of dispase being used for digestion of the tissue. Considering the time of incubation, Wada et al prolonged a general incubation time from one hour to two hours. All studies utilized $70 \mu \mathrm{m}$ cell strainer to strain the tissue. In addition to this isolation method, PDLSCs give rise to cells like osteoblasts, odontoblasts, chondroblasts, Adipocytes, chondrocytes, cementoblasts.

The second most common tissue that was being used in isolation is dental pulp. Dental pulp stem cells were isolated at first by Gronthos and his colleagues (26). Under appropriate growth factors, DPSCs also differentiated in adipocytes and neural-like cells. In the studies included, DPSCs give rise to cells like odontoblasts, osteoblasts, neuroblasts, angioblast, adipocytes ad chondrocytes. Under appropriate growth factors, DPSCs also differentiated in adipocytes and neural-like cells. Even in 2005, Shi et al. (27) questioned whether stem cells could be helpful in dental tissue regeneration, raising doubts on the potential of stem cell research, since not much was achieved beyond the mere observation of their presence at five years from first observation. Moreover, in 2005, Laino et al. (28) showed how DPSCs are still detectable in patients over 30 and that there were no substantial differences with younger cells. Like periodontal ligament, studies describing about the isolation process from dental pulp was not same for all the five studies mentioned. In 3 studies, 3 $\mathrm{mg} / \mathrm{ml}$ of collagenase $\mathrm{I}(13,15,19)$ and 1 study used 0.2 $\mathrm{mg} / \mathrm{ml}$ of type I collagenase (15) for isolation. The incubation period of a study by Karbanova et al., where the time was increased to 70 mins than usual 60 mins. A large number of cells could be able to differentiate from the dental pulp and they are: osteoblasts, odontoblasts, adipocytes, neuroblast, angioblast, chondrocytes.

Alveolar bone fragments that is obtained along with the tooth was usually used for isolation of the cells. Two studies included, describes about the isolation of cells from the alveolar bone. One study did not digest using collagenase and dispase (12) and other used $3 \mathrm{mg} / \mathrm{ml}$ type I collagenase and $4 \mathrm{mg} / \mathrm{ml}$ type I dispase (17). Incubation time for former study was not mentioned and later it was 60 mins. The cells that were differentiated from this are osteoblasts, odontoblasts, chondroblasts, adipocytes.

Dental papilla has been considered to be the source of odontoblasts during tooth development. As the differentiated odontoblasts lay down the primary dentin, the dental papilla becomes encased within the dentin structure and evolves into pulp tissue. The apical end of the dental papilla, however, has not been discussed much in the literature. It is generally believed that the formation of root dentin is the result of signaling from HERS to the adjacent undifferentiated mesenchymal cells which then turn into odontoblasts that are responsible for the root dentin formation. The anatomical location of these undifferentiated mesenchymal cells has not been clearly elucidated. They may be residing either in pulp or apical papilla. In this review, 2 articles described about isolation from apical papilla $(15,18)$. Both the studies as a process of digestion used $3 \mathrm{mg} / \mathrm{ml}$ collagenase $\mathrm{I}$ and $4 \mathrm{mg} / \mathrm{ml}$ dispase I. But there was a variation in the incubation period. A study by Jo et al., where he digested for a period of one hour and Jiayuan Wu used $40 \mathrm{~min}$ of incubation time. Cells that were differentiated from apical papilla include osteoblasts, odontoblasts, osteocytes and adipocytes. The common marker used for differentiation are STRO-1. In addition to this osteoblasts and odontoblasts expressed OCT-4, Nanog, Sox2, and Rex1. The expansions of given abbreviations are described in Table 3.

\section{Conclusion}

1. The review highlights about the various source of isolation of stem cells from different regions of the oral cavity. It also emphasizes on the different methods of 
characterization of stem cells into various lineages using markers like STRO-1, Nanog, OCT-4.

2. From 13 studies, four studies described about isolation from PDL and four from dental pulp. Although it was from the same source, no homogeneity observed in methodology of isolation of stem cells and there was no standardized protocol that was being followed.

3. Similarly there is a heterogenicity observed in using the markers for characterization of stem cells from same source.

4. With the data obtained, it cannot be concluded that a particular source from the oral cavity is feasible and common source for isolation which is a result of heterogeneity in the methodology.

5. Therefore, there is some lacunae in the standardization of method of isolation of stem cells and its characterization. Hence further research should be aimed at framing a protocol for standardization of stem cells in isolation and differentiation.

\section{Potential conflict of interest}

The authors have no conflicting financial interest.

\section{References}

1. Haeckel E. Historie de La créacion dês etres organisés. 3rd ed. Paris: Librairie C. Reinwald; 1903

2. Thomson JA, Kalishman J, Golos TG, Durning M, Harris CP, Becker RA, Hearn JP. Isolation of a primate embryonic stem cell line. Proc Natl Acad Sci U S A 1995;92:7844-7848

3. Weissman IL, Anderson DJ, Gage F. Stem and progenitor cells: origins, phenotypes, lineage commitments, and transdifferentiations. Annu Rev Cell Dev Biol 2001;17:387403

4. Smith AG. Embryo-derived stem cells: of mice and men. Annu Rev Cell Dev Biol 2001;17:435-462

5. Silva LB, Neto AP, Pacheco RG, Júnior SA, de Menezes RF, Carneiro VS, Araújo NC, da Silveira MM, de Albuquerque DS, Gerbi ME, Álvares PR, de Arruda JA, Sobral AP. The Promising Applications of Stem Cells in the Oral Region: Literature Review. Open Dent J 2016;10:227-235

6. Jamal M, Chogle S, Goodis H, Karam SM. Dental stem cells and their potential role in regenerative medicine. $\mathrm{J}$ Med Sci 2011;4:53-61

7. Mattioli-Belmonte M, Teti G, Salvatore V, Focaroli S, Orciani $M$, Dicarlo $M$, Fini $M$, Orsini G, Di Primio R, Falconi M. Stem cell origin differently affects bone tissue engineering strategies. Front Physiol 2015;6:266

8. Kato H, Katayama N, Taguchi Y, Tominaga K, Umeda M, Tanaka A. A synthetic oligopeptide derived from enamel matrix derivative promotes the differentiation of human periodontal ligament stem cells into osteoblast-like cells with increased mineralization. J Periodontol 2013;84:14761483

9. Kim SS, Kwon DW, Im I, Kim YD, Hwang DS, Holliday LS, Donatelli RE, Son WS, Jun ES. Differentiation and characteristics of undifferentiated mesenchymal stem cells originating from adult premolar periodontal ligaments. Korean J Orthod 2012;42:307-317

10. Seo BM, Miura M, Gronthos S, Bartold PM, Batouli S, Brahim J, Young M, Robey PG, Wang CY, Shi S. Investigation of multipotent postnatal stem cells from human periodontal ligament. Lancet 2004;364:149-155

11. Gay IC, Chen S, MacDougall M. Isolation and characterization of multipotent human periodontal ligament stem cells. Orthod Craniofac Res 2007;10:149-160

12. Karbanová J, Soukup T, Suchánek J, Pytlík R, Corbeil D, Mokrý J. Characterization of dental pulp stem cells from impacted third molars cultured in low serum-containing medium. Cells Tissues Organs 2011;193:344-365

13. Yu J, He H, Tang C, Zhang G, Li Y, Wang R, Shi J, Jin Y. Differentiation potential of STRO-1+ dental pulp stem cells changes during cell passaging. BMC Cell Biol 2010; 11:32

14. Laino G, d'Aquino R, Graziano A, Lanza V, Carinci F, Naro F, Pirozzi G, Papaccio G. A new population of human adult dental pulp stem cells: a useful source of living autologous fibrous bone tissue (LAB). J Bone Miner Res 2005;20:1394-1402

15. Jo YY, Lee HJ, Kook SY, Choung HW, Park JY, Chung $\mathrm{JH}$, Choung YH, Kim ES, Yang HC, Choung PH. Isolation and characterization of postnatal stem cells from human dental tissues. Tissue Eng 2007;13:767-773

16. Wu J, Huang GT, He W, Wang P, Tong Z, Jia Q, Dong L, Niu Z, Ni L. Basic fibroblast growth factor enhances stemness of human stem cells from the apical papilla. J Endod 2012;38:614-622

17. Fawzy El-Sayed KM, Paris S, Becker S, Kassem N, Ungefroren H, Fändrich F, Wiltfang J, Dörfer C. Isolation and characterization of multipotent postnatal stem/progenitor cells from human alveolar bone proper. J Craniomaxillofac Surg 2012;40:735-742

18. Wada N, Wang B, Lin NH, Laslett AL, Gronthos S, Bartold PM. Induced pluripotent stem cell lines derived from human gingival fibroblasts and periodontal ligament fibroblasts. J Periodontal Res 2011;46:438-447

19. Kim SW, Lee IK, Yun KI, Kim CH, Park JU. Adult stem cells derived from human maxillary sinus membrane and their osteogenic differentiation. Int J Oral Maxillofac Implants 2009;24:991-998

20. Hung TY, Lin HC, Chan YJ, Yuan K. Isolating stromal stem cells from periodontal granulation tissues. Clin Oral Investig 2012;16:1171-1180

21. Bartold PM, McCulloch CA, Narayanan AS, Pitaru S. Tissue engineering: a new paradigm for periodontal regeneration based on molecular and cell biology. Periodontol 2000 2000;24:253-269 
22. Morsczeck C, Götz W, Schierholz J, Zeilhofer F, Kühn U, Möhl C, Sippel C, Hoffmann KH. Isolation of precursor cells (PCs) from human dental follicle of wisdom teeth. Matrix Biol 2005;24:155-165

23. Gronthos S, Arthur A, Bartold PM, Shi S. A method to isolate and culture expand human dental pulp stem cells. Methods Mol Biol 2011;698:107-121

24. Gronthos S, Mankani M, Brahim J, Robey PG, Shi S. Postnatal human dental pulp stem cells (DPSCs) in vitro and in vivo. Proc Natl Acad Sci U S A 2000;97:13625-13630

25. Kaku M, Komatsu Y, Mochida Y, Yamauchi M, Mishina $\mathrm{Y}$, Ko CC. Identification and characterization of neural crest-derived cells in adult periodontal ligament of mice.
Arch Oral Biol 2012;57:1668-1675

26. Gronthos S, Zannettino AC, Hay SJ, Shi S, Graves SE, Kortesidis A, Simmons PJ. Molecular and cellular characterisation of highly purified stromal stem cells derived from human bone marrow. J Cell Sci 2003;116:1827-1835

27. Shi S, Bartold PM, Miura M, Seo BM, Robey PG, Gronthos S. The efficacy of mesenchymal stem cells to regenerate and repair dental structures. Orthod Craniofac Res 2005; 8:191-199

28. Laino G, Graziano A, d'Aquino R, Pirozzi G, Lanza V, Valiante S, De Rosa A, Naro F, Vivarelli E, Papaccio G. An approachable human adult stem cell source for hard-tissue engineering. J Cell Physiol 2006;206:693-701 